\section{PENNSYLVANIA OIL REGIONS}

THREE years ago the Second Geological Survey of Pennsylvania, under the able leadership of $\mathrm{Mr}$. J. P. Lesley, published a report on the oil-well records of the State - a laborious compilation by Mr. J. F. Carll. During the interval the value of this report has been duly tested and acknowledged. It is a treasury of facts classified and indexed for the guidance of the compiler of statistics, the well-sinker, the mining engineer and the geologist, while the general reader may learn much of interest from its pages. Another report by the same author is just about to appear. It forms a volume of about 500 pages with two indexes, twenty-three plates, and an atlas of twenty-two sheets of maps, well-sections, and working drawings of machinery and tools. We have been favoured with advance-sheets of the Letter of Transmission prefixed to the report by Mr. Lesley, from which we make the following extracts:-

"The main featurz of the report is the settlement of the true character of the Venango oil-sand group as a distinct and separate deposit, with characteristic marks distinguishing it from the Palæozoic formations of a preceding and a succeeding age; the differentiation of the group into three principal and other subordinate layers of gravelly sand, holding more or less oil or gas; the local variability of these sands, their singular persistency beneath long and narrow belts of country, their change into barren shales elsewhere, and their independence of other oil-bearing sands and shales of an earlier and of a later date."

Some characteristically caustic remarks are made as to the consequences of the contempt entertained by "practical" men for what they consider the "theoretical" opinions of geologists, and a flagrant example is given of the results of trusting to mere empirical guidance. These passages ought to be well studied by oil-men in Pennsylvania and Canada. Mr. Lesley goes on to relate an incident in his own experience. "In $184 \mathrm{I}$," he says, "I was ordered by the chief of the First Geological Survey to report on the counties lying along the New York State line, and down the eastern bank of the Allegheny River, as far as the Kiskiminitas. Other assistants on that survey had already discovered and reported the geological structure of the Allegheny River and Beaver River water basins, and the rate of descent of the rocks southward and south-westward in relation to tide level had been calculated. My business was to follow and locate upon the map the anticlinal and synclinal rolls which locally change and modify this general dip, and to identify the principal coal beds over a large area.

"After the discovery of petroleum (which of course did not in the least set aside or essentially change the structure of Western Pennsylvania as established by the First Survey), I happened to be employed by the Brady's Bend Company to examine their property, and to give them, among other items, an opinion upon the probable existence and depth of oil beneath it. To do this, I merely did what any geologist who had thoroughly studied that country would have done; I calculated the vertical distance from the oil sand on Oil Creek up to coal A, then I calculated the dip of the measures between Oil Creek and Brady's Bend, and then I identified coal A at Brady's Bend. I reported that the Venango oil sand, if it extended under ground as far as Brady's Bend, ought to lie at IIO0 feet beneath water-level. Any geologist who knew the country could have done this. It required no genius, no uncommon knowledge, nothing but a plain, simple, systematic, or scientific, in other words, true theoretical method of applying known facts for discovering the unknown. Any oil-man could have done the same if he had noticed the rocky layers as he went up and down the river, and put this and that carefully together.
"Yet, when after a few months, oil was actually struck at Brady's Bend within a few feet of the depth which I had assigned to it, the astonishment of all classes of oil-men was ludicrously extravagant; a score or two of copies were made from the manuscript report, and these copies passed from hand to hand as precious things, and their author was looked upon as a prodigy of mental penetration, and was offered large sums of money to locate wells in different districts, none of which offers, of course, were accepted, because he was as ignorant of the actual existence of an oil-bearing sand in any given locality as everybody else.

"The story has its moral. Let 'practical' men believe in and respect the slowly, carefully reached conclusions of 'theoretical' men enough to take them into consideration, so far as to comprehend them, and to govern themselves by them in their own collection and collation of facts relating to their own pecuniary interests.'

Notwithstanding the amount of detailed information now collected regarding the occurrence of the liquid hydrocarbons in these ancient American formations, it must be frankly confessed that we seem to be as far as ever from a clue to their source and history. "The origin of petroleum," says Mr. Lesley, "is still an unsolved problem, and Chapter 26 of this Report merely suggests queries respecting it. That it is in some way connected with Palæozoic sea-weeds, the marks of which are so infinitely abundant in the rocks, and with the infinitude of coralloid sea-animals, the skeletons of which make up a large part of the limestone formations which lie several thousand feet beneath the Venango oil-sand group, scarcely admits of dispute ; but the exact process of its manufacture, of its transfer, and of its storage in the gravel beds, is utterly unknown. That it ascended rather than descended into them seems indicated by the fact that the lowest sand holds oil when those above do not, and that upper sands hold oil where they extend beyond or overhang the lower. The chemical theory, so-called, which looks upon petroleum as condensed from gas, the gas having been previously distilled from the great black shale formations (Marcellus and Genessee), must face the objection that such a process, if chemically possible, which is doubtful, ought to have distributed the oil everywhere, and permanently blackened and turned into bituminous shales the entire thickness of this part of the earth crust, several thousand feet thick. It fails to explain the petroleum obtainable from the Cannel coals, and from the roof shales of bituminous coal beds. And it fails also to explain the entire absence of petroleum from immense areas of not only shales, but sand and gravel rocks equally underlaid by the Marcellus and Genessee formations."

One of the most generally interesting questions in the report is one discussed in great detail by Mr. Carll-an episode in the history of the glacial period in North America. Certain oil-bearing river-gravels are connected with a very thick "deposit of Canadian rock fragments not only upon the surface, but to the depth of several hundred feet beneath it in Northern Pennsylvania, a deposit which forms a great belt, more than a thousand miles long, across the continent from Cape Cod in Massachusetts to Iowa and Minnesota beyond the Mississippi River. It was brought from the north by a vast sheet of moving ice which filled the great lakes and rode over the highest mountains to the south of themburying all New England and New York, Northern New Jersey, Northern Pennsylvania, the Western Reserve in Ohio, and large portions of the States lying further west - projecting long tongues or slowly moving torrents of solid ice southward as far as and even beyond the Ohio River in Kentucky. It drove slowly before it the reindeer, musk ox, caribou, moose, and other Arctic animals whose bones are found in the diluvial clays of the Kentucky caves; while the walrus inhabited the shores 
of the Atlantic as far south as the Ashley River in South Carolina. The Esquimaux race no doubt accompanied these animals into the Gulf States, just as it did in France as far south as the Pyrenees. By the deposit of this vast pile of moraine matter, sand, clay, scratched rocks and huge boulders, the valleys by which our rivers had previously flowed into Lake Erie were filled up so that the waters were turned southward into the Ohio."

\section{"THOUGHT-READING"}

THE public mind has of late been somewhat agitated by the doings of a Mr. Bishop, who has come before the world of London society in a capacity no less startling than that of a professed reader of thought. Armed with a favourable letter of introduction from Dr. W. B. Carpenter, he has not only taken by storm the general public and daily press, but also succeeded in convening an assembly of scientific men to witness his performance, which in point of numbers and importance resembled in miniature a soirée of the Royal Society, while still more recently he has had the honour of exhibiting his powers before the Heir Apparent to the Crown. There is no doubt that Mr. Bishop owes this wide and sudden celebrity to the patronage which was extended to him by the great opponent of all humbug; and although Dr. Carpenter doubtless intended his letter to exert a salutary influence by recommending $\mathrm{Mr}$. Bishop to the attention of the credulous, it is to be regretted that it served to recommend him also to the attention of the scientific. This is to be regretted, because the result was to endow the powers which were afterwards exhibited with a fictitious degree of importance in the eyes of the public, and also to bring a large number of distinguished men into the somewhat undignified position of acting the stalking-horse to Mr. Bishop's notoriety. But however this may be, it seemed to Prof. Croom Robertson worth while to make a more careful trial of Mr. Bishop's powers than was possible in the first crowded assembly, and he therefore invited Mr. Francis Galton, Prof. E. R. Lankester, and myself, who were all present on the first occasion, to join him in an investigation. When we had assented to the proposal, Mr. Bishop was invited to meet us at Prof. Croom Robertson's house. He immediately accepted the invitation, and it is but just to state that throughout the investigation which followed he placed himself entirely in our hands, and with the utmost good nature submitted to all our requirements. He professes that he is himself ignorant of his modus operandi, and merely desires that this should be adequately investigated and satisfactorily explained.

Two meetings were arranged. At the first, which was held on May 28, Prof. Lankester was not able to attend, and his place was taken by Mr. Leslie Stephen. Mr. Alfred Sidgwick was also present. At the second meeting, held on June II, there were present as before, Prof. Croom Robertson, Mr. F. Galton, and myself, but Mr. Leslie Stephen and Mr. Alfred Sidgwick were absent, while Prof. Lankester was present. The room in which both meetings were held was a double drawing-room of the ordinary shape of those which usually have foldingdoors; here however the folding-doors were absent. The extreme length of the room was 36 feet, the width of its front part was I9 feet, and of its back part 12 feet.

First, Mr. Bishop was taken out of the room by me to the hall down stairs, where I blindfolded him with a handkerchief; and, in order to do so securely, I thrust pieces of cotton-wool beneath the handkerchief below the eyes. In all the subsequent experiments Mr. Bishop was blindfolded, and in the same manner. While I was doing this, Mr. Sidgwick was hiding a small object beneath one of the several rugs in the drawing-room; it having been previously arranged that he was to choose any object he liked for this purpose, and to conceal it in any part of the drawing-room which his fancy might select. When he had done this the drawing-room door was opened and the word "Ready" called. I then led Mr. Bishop up stairs, and handed him over to Mr. Sidgwick, who at that moment was standing in the middle line between the two drawing-rooms, with his back to the rug in question, and at a distance from it of about 15 feet. Mr. Bishop then took the left hand of Mr. Sidgwick, placed it on his (Mr. Bishop's) forehead, and requested him to think continuously of the place where the object was concealed. After standing motionless for about ten seconds $\mathrm{Mr}$. Bishop suddenly faced round, walked briskly with Mr. Sidgwick in a direct line to the rug, stooped down, raised the corner of the rug, and picked up the object. In doing all this there was not the slightest hesitation, so that to all appearance it seemed as if Mr. Bishop knew as well as Mr. Sidgwick the precise spot where the object was lying.

This is Mr. Bishop's favourite experiment; so I may give some of our other observations relating to it before passing on to the variations which we introduced. It was soon found that he succeeded much better with some of us than with others; so at the second meeting, in order to make a numerical comparison, he was requested to try two experiments with each of the four persons who were present. With Mr. Galton, Prof. Robertson, and Prof. Lankester he failed utterly, while with myself he succeeded once perfectly and the second time approximately. For on the first occasion I concealed a pocket-matchbox upon the top of a book behind the leather lap of a book-shelf. After feeling along the rows of books for some time he drew out the one on which the matchbox was lying. In the second experiment I placed a visiting-card on the key-board of a grand piano and closed the cover. After going about the room in various directions for a considerable time he eventually localised the piano, and brought his finger to rest upon its upper surface about six inches from the place where the card was lying. It will thus be seen that his success with me, although so much better than with any of the other three persons present that evening, was not so immediate and precise as it had been with Mr. Sidgwick the evening before. It has also to be mentioned that in one of the experiments which he tried with Prof. Robertson the evening before, he was, after a good deal of feeling about, successful in localising a particular spot on an ordinary chair which Prof. Robertson had selected as the spot to be found. From this it will be seen that it made no difference whether a particular article or a particular spot was thought of ; for if the subject thought of was a certain square inch of surface upon any table, chair, or other object in the room, Mr. Bishop, in his successful experiments, would place his finger upon that spot. Neither did it make any difference whether the article or place thought of was at a high or a low elevation. Thus, for instance, in one of the experiments I placed a small pencil-case high up in the chandelier of one of the drawing-rooms. There was first a great deal of walking about in various directions, examining tables, bookshelves, \&c., so that it was thought that the experiment was about to prove a failure. (It may here be mentioned parenthetically that in all the experiments tracings were taken of the routes which Mr. Bishop traversed, but it seems needless to occupy space with recording the analysis 0 these results.) Then, while feeling over the surface of a tabla in the other drawing-room, and not far from the corresponding chandelier, Mr. Bishop suddenly pointed at arm's length vertically to the ceiling. He remained motionless in this position for a few seconds, and then set off at a brisk pace in a straight line to the other drawing-room, until he came beneath the other chandelier. As his finger was all this time pointing to the ceiling, it 